\title{
Gnathopleura quadridentata Wharton, 1986 (Hymenoptera; Braconidae; Alysiinae) and their hosts collected in different substrates in Caldas Novas, Goiás
}

\author{
Marchiori, $\mathrm{CH} .{ }^{*}$ \\ Centro Federal de Educação Tecnológica de Urutaí-UNED-Morrinhos, Br 153, Km 633, \\ CP 92, CEP 75650-000, Morrinhos, GO, Brazil \\ *e-mail: chmarchiori@yahoo.com.br
}

Received March 30, 2005 - Accepted July 27, 2005 - Distributed February 28, 2007

(With 1 figure)

The Diptera are an excellent model for studying synanthropy, not only because their ecological importance, but also because their medical-veterinary characteristics as vectors for etiological agents such as ameba cysts, helminth eggs, pathogenic enterobacteria, viruses and fungi (Greenberg, 1971; D’Almeida, 1992).

It is known that fly control using insecticides usually selects resistant populations. Mendes and Linhares (1993) stated that new methods for fly control are needed, and one possible method for controlling these insects is the use of natural enemies such as parasitoids. Such agents may be responsible for reducing the sizes of synanthropic fly populations in nature.

The Hymenoptera are one of the largest orders of insects and one of the most important groups of parasitoids that develop in or on immature forms (egg, larvae, pupae, or adults) of other arthropods. Approximately $50 \%$ of all Hymenoptera are parasitoids, and they are of considerable importance as control agents for insect pests (Askew, 1971).

The Braconidae are one of the largest Hymenoptera families, with approximately 40,000 species (Sharkey, 1993), divided into 45 subfamilies (Achterberg, 1992). The most common hosts of braconids are the larvae of Lepidoptera, Coleoptera and Diptera.

The Alysiinae are a large subfamily of Braconidae containing over 1,000 described species worldwide. All alysiines are koinobiont endoparasitoids of cyclorrhaphous Diptera (Wharton, 1984). They larviposit or oviposit on the host, the larvae penetrate into the host and the adults emerge from the puparia.

The species definition of Gnathopleura quadridentata Wharton (Hymenoptera; Braconidae; Alysiinae) is based on the following characteristics: mandible border between teeth 1 and 2 swollen to form a fourth tooth; parallel vein arising near upper edge of brachial cell; post-nervellus well developed, extending more than halfway towards the wing margin as a pigmented vein (Penteado-Dias, 1995); and abdomen entirely black in both sexes, with only petiole and occasionally terga $2+3$ orange (Figure 1 ).
The objective of this note is to report on the occurrence of the parasitoid of $G$. quadridentata in different substrates in the Park of the mountain range of Caldas Novas, State of Goiás.

The study was conducted in a wooded area of the Park of the mountain range of Caldas Novas State of Goiás, located in the vicinity of the city of Caldas Novas, State of Goiás $\left(18^{\circ} 25^{\prime} \mathrm{S}\right.$ and $\left.49^{\circ} 13^{\prime} \mathrm{W}\right)$, Brazil. The flies were attracted to traps consisting of dark-colored cylindrical metal cans, measuring $19 \mathrm{~cm}$ height and $9 \mathrm{~cm}$ diameter, with two openings measuring $30 \mathrm{~mm}$ in width, located in the lower third of the can, to allow flies to enter. A more detailed description of the traps is given by Ferreira (1978). Human feces, fish, bovine liver, and chicken served as bait for attracting the flies. Sixteen traps were used, spaced two meters apart. These were hung on trees at a height of one meter above the ground. Four traps were utilized for each type of bait. The collected insects were taken to the laboratory, sacrificed using ethyl ether and kept in $70 \%$ alcohol for further identification. The baits were removed from the traps and placed in plastic containers with a layer of sand to form the substratum for the larvae to pupate in. The sand was then sifted to collect the pupae. These were then placed individually in gelatin capsules ( 00 number) and kept until the emergence of the flies or their parasitoids.

The specimens were stored in the Biology Laboratory of Instituto Luterano de Ensino Superior de Itumbiara, GO, Brazil. The parasitism percentage was calculated using the following formula: $\mathrm{P}=\left(\mathrm{n}^{\mathrm{o}}\right.$. of parasitized pupae/total pupae) $\times 100$. The host preference of the parasitoid $G$. quadridentata was evaluated using the chisquared statistical test.

Between August 2003 and July 2004, 958 puparia of three species of Diptera were collected. From these, 104 specimens of the parasitoid G. quadridentata emerged (Table 1). The percentage of parasitism obtained was $10.9 \%$.

Gnathopleura quadridentata shows preference for calyptrate muscoid flies, especially sarcophagids (Shenefelt, 1974). This parasitoid is solitary and emerges from the puparium of the host. Species of Gnathopleura 
Table 1. Gnathopleura quadridentata and its hosts, collected from various substrates in Caldas Novas, State of Goiás, between August 2003 and July 2004.

\begin{tabular}{|c|c|c|c|c|c|}
\hline Substrate/Diptera species & Frequency & Specie & Frequency & $\begin{array}{c}\mathrm{N}^{\circ} \text { of parasitized } \\
\text { pupae }\end{array}$ & $\begin{array}{c}\text { Percentage } \\
(\%)\end{array}$ \\
\hline \multicolumn{6}{|l|}{ Human feces } \\
\hline Oxysarcodexia thornax & 169 & G. quadridentata & 25 & 25 & 14.8 \\
\hline Sarcodexia lambens & 50 & G. quadridentata & 28 & 28 & 56.0 \\
\hline \multicolumn{6}{|l|}{ Bovine liver } \\
\hline Oxysarcodexia thornax & 166 & G. quadridentata & 1 & 1 & 0.6 \\
\hline Peckia chrysostoma & 99 & G. quadridentata & 4 & 4 & 4.0 \\
\hline \multicolumn{6}{|l|}{ Chicken } \\
\hline Oxysarcodexia thornax & 101 & G. quadridentata & 17 & 17 & 16.8 \\
\hline Peckia chrysostoma & 160 & G. quadridentata & 20 & 20 & 12.5 \\
\hline \multicolumn{6}{|l|}{ Fish } \\
\hline Oxysarcodexia thornax & 213 & G. quadridentata & 9 & 9 & 4.2 \\
\hline Total & 958 & & 104 & 104 & 10.9 \\
\hline
\end{tabular}

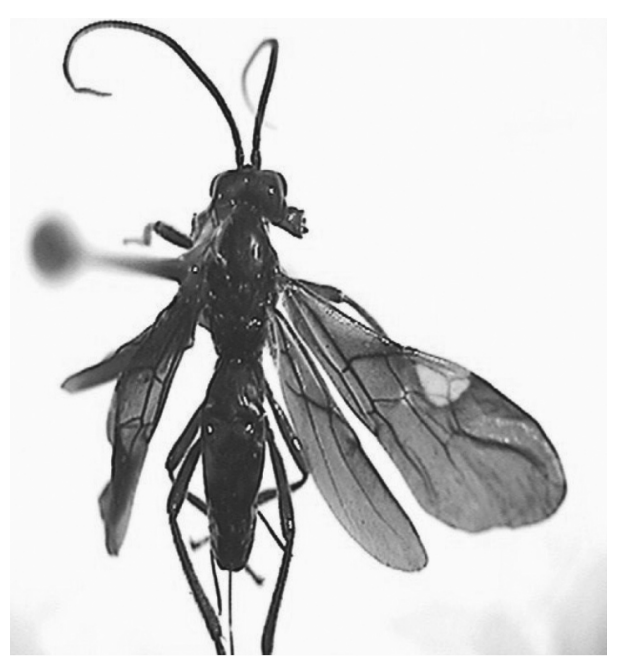

Figure 1. General aspect of Gnathopleura quadridentata.

have been released for biological control of sarcophagids and muscids (Wharton, 1979).

The greatest numbers of parasitoids ( 28 specimens) and the greatest frequency of parasitism (56.0\%) were found in bovine liver, in the host Sarcodexia lambens (Diptera; Sarcophagidae). This was probably due to variations in quality and availability of food resources. Sarcodexia lambens is widely distributed in the Americas, and is found from the South of the United States of America to Argentina (Lopes and Leite, 1989). This species colonizes organic material of animal nature that is used as bait, such as human feces, bovine faces and bovine liver (Rocha and Mendes, 1996; Marchiori et al., 2000).

The species with the second greatest frequency of parasitism was Oxysarcodexia thornax (Walker) (Diptera: Sarcophagidae), with a rate of $16.8 \%$. This species was also collected from all the bait types utilized. This was possibly because of its capacity to colonize many different types of substrate of animal origin. Oxysarcodexia thornax has also been collected from bait in Itumbiara, State of Goiás: 23 specimens from human feces, 31 from fish and 46 from bovine kidneys. Previously, this species had been collected from the same municipality, from bovine liver and feces (Marchiori, 2000; Marchiori et al., 2000).

Peckia chrysostoma (Wiedemann) (Diptera: Sarcophagidae) is a widely distributed neotropical synanthropic species (Ferraz, 1995). In Rio de Janeiro, this species has shown preference for environments inhabited by humans, and it is primarily attracted to raw fish (D'Almeida, 1984).

Gnathopleura quadridentata has presented preference for $S$. lambens in human feces; for $P$. chrysostoma in bovine liver and chicken; and for $O$. thornax in fish $\left(X^{2}=69.26\right.$; GL: 6; $\left.p<0.05\right)$.

The use of chemical substances to control this fly may result in high production costs. Moreover, this may render fruit unfit for exportation, cause damage to the environment and harm human health as well. Thus, searching for effective natural enemies may provide a viable alternative method for containing this pest through a long-term control program.

\section{References}

ACHTERBERG, VC., 1992. Bentonia gen. nov. (Hymenoptera: Braconidae: Orgilinae) from Brazil. Zool. Mede., vol. 66, p. 340-344.

ASKEW, RR., 1971. Parasitic insects. Heinemann Educational Books, London, 316p.

D'ALMEIDA, JM., 1984. Sinantropia de Sarcophagidae (Diptera) na região metropolitana do Estado do Rio de Janeiro. Arq. Univ. Fed. Rur. Rio de J., vol. 7, no. 2, p. 101-110.

D'ALMEIDA, JM., 1992. Calyptrate Diptera (Muscidae and Anthomyiidae) of the State of Rio de Janeiro - I. Synanthropy. Mem. Inst. Oswaldo Cruz, vol. 87, no. 3, p. 381-386. 
FERRAZ, MV., 1995. Larval and pupal periods of Peckia chrysostoma and Adiscochaeta ingens (Diptera: Sarcophagidae) reared under laboratory conditions. Mem. Inst. Oswaldo Cruz, vol. 90 , no. 5, p. 611-614.

FERREIRA, MJM., 1978. Sinantropia de dípteros muscóideos de Curitiba, Paraná: Calliphoridae. Rev. Bras. Biol., vol. 38 , no. 2 , p. 445-454.

GREENBERG, B., 1971. Flies and disease - ecology, classification and biotic association. Princeton University Press, New Jersey, 856p.

LOPES, HS. and LEITE, ACR., 1989. Morphology of the egg of Sarcodexia lambens (Diptera: Sarcophagidae). Mem. Inst. Oswaldo Cruz, vol. 84, no. 4, p. 497-500.

MARCHIORI, CH., 2000. Parasitóides de estágios imaturos de dípteros sinantrópicos coletados em vários ambientes em Itumbiara-GO. Acta Scientiarum, vol. 22, no. 3, p. 655-661.

MARCHIORI, CH, CASTRO, MEV, PAIVA TCG, SILVA CG. and TEIXEIRA, FF., 2000a. Dípteros muscóides de importância médica e veterinária e seus parasitóides em Goiás. Arq. Bras. Med. Vet. Zootec., vol. 52, no. 4, p. 350-353.
MENDES, J. and LINHARES AX., 1993. Atratividade por iscas, sazonalidade e desenvolvimento ovariano em várias espécies de Muscidae (Diptera). Rev. Bras. Ent., vol. 37, no. 2, p. 289-297.

PENTEADO-DIAS AM., 1995. Notes on the biology of Gnathopleura sp. (Hymenoptera: Braconidae) in Brazil. Entomol. News, vol. 106, no. 3, p. 127-129.

ROCHA, UR. and MENDES, J., 1996. Pupation of Dermatobia hominis (L. Jr., 1781) (Diptera: Cuterebridae) associated with Sarcodexia lambens (Wiedemann, 1830) (Diptera: Sarcophagidae). Mem. Inst. Oswaldo Cruz, vol. 91, no. 3, p. 299-300.

SHARKEY, MJ., 1993. Family Braconidae. In: GOULET, H. and HUBER, JT. Hymenoptera of the world: An identification guide to families. Ottawa, Research Branch Agriculture Canada Publication, vol. 1, p. 362-395.

SHENEFELT, RD., 1974. Braconidae 7, Alysiinae. In: VECHT, JVD. and SHENEFELT, RD. (eds.), Hymenopterorum Catalogus (new edition), part 11. Junk, The Hague, p. 937-1113. 